\title{
Influence of Community Policing on Incidences of Criminal Activities in Low Income Areas of Nakuru Town, Kenya
}

\author{
Kennedy O. Ogutu ${ }^{1}$, Mark I.O.Okere ${ }^{1}$, Erick Bor ${ }^{2}$ \\ ${ }^{l}$ Department of Curriculum, Instruction \& Educational Management, Egerton University \\ ${ }^{2}$ Department of Peace, Security\& Social Studies, Egerton University
}

*Corresponding Author: Kennedy O. Ogutu, Department of Curriculum, Instruction \& Educational Management, Egerton University

\begin{abstract}
This study investigated the influence of community policing on incidences of criminal activities in low income areas of Nakuru Town in Kenya. In this study, only the criminal activities of theft and break-ins were studied. Cross-sectional survey research design was used. The target population was all the residents in four low income areas of Nakuru Town having a combined population of 252,762. A total of 156 respondents participated. The respondents were drawn purposively from each of the four low income areas of Nakuru Town. A questionnaire was used to gather information from the residents. Hypotheses were tested using Pearson's Correlation Coefficient (r) statistic at $\alpha=0.05$ level of significance. The results obtained from some of the areas gave statistically significant influence of community policing on incidences of theft and break-ins in low income areas of Nakuru Town. There also appears to be no statistically significant influence of community policing on incidences of theft and break-ins in some areas. This implies that community policing is not working uniformly in the areas studied. The findings from this study inform the county government of Nakuru and Kenya at large, on whether community policing which was introduced to reduce and prevent crimes has actually had an influence in the frequency of occurrence of the most prevalent crimes (theft and break-ins).
\end{abstract}

Keywords: Community policing, crime, theft, break-ins, low income areas.

\section{INTRODUCTION}

Crime refers to a form of deviance that involves an infraction of the criminal law. A crime may also involve any offence that is against a public law, a term that in its most general sense entails all offences (Allen \& Michael, 2005).Crimes are normally defined and punished by statutes such as Penal Code (PC) and common law. In fact, they are 'mala in se' or bad in themselves and 'mala prohibita' or bad because prohibited including all offences against the moral law. Crimes happen everywhere around the world. Examples of crime include; sodomy, adultery, incest, bigamy and fornication, public indecency, drunkenness, violating the grave, homicide, mayhem, rape and defilement, kidnappings, poisoning, assault and battery, false imprisonment, abduction, domestic violence cases, burglary, arson, Armed robbery, larceny, forgery, theft, housebreaking, break-ins, and drug/firearm trafficking and possession among others (Lafave\& Edward, 2001). They have devastating effectson human beings. For example, crimes lead to loss of lives, body injuries, psychological trauma, fear, displacements, and destruction of property among others. It is because of the above reasons that security intervention strategies such as community policing was initiated to try and reduce these effects (McGoey, 2013).

Community policing is a security intervention strategy that emphasizes on the support of problem solving tactics involving partnerships between the police and the community so as to address the causes and reduce fear of crimes and social disorders. The history of community policing can be traced back to have begun one and half a century ago in London during the London Metropolitan Police District formation.Community policing as a security intervention strategy was then adopted by England and United States in the late $18^{\text {th }}$ Century and early $19^{\text {th }}$ Century (Walker, 1994). The two countries came up with a new strategy of community policing known as team policing in the 1970s 
which recognized that prior to the introduction of community policing, social climate and techniques of police patrol made the police become isolated from the community making the fight against crime very difficult. Wilson and Kelling (1982) further outline that team policing proceeded to assign a neighborhood to a group of police officers who were expected to learn about the neighborhood members, neighborhood itself and the problems experienced. This method was tried in several parts of the United States of America and was found to be successful in places such as California, in the early mid-1990s. Naude (1999) posits that the outcomes were that the relationship between the community and the police through working in cahoots did immensely resolve and prevent community crimes and social disorders. Community policing is a security intervention strategy which requires the police and the citizens to join together as partners in fighting crime and disorder through balancing reactive responses to calls for service with proactive problem solving majorly centered on the causes of crime and disorder (Diamond \& Weiss, 2009).

In Africa, community policing has been noticed to be successful in places where interactions have been more informal according to Naude (1999). In Nigeria, for example, people have deviated from formal to informal law in an attempt to curb the menace of crime by forming informal ethnic militia groups to provide protection (Rotimi, 2001). Some communities such as the Igbo community of South Eastern Nigeria have put much emphasis on their traditional customs and values as well as other unwritten concepts of law to interpret what law is. For example, they believed that the behavior of citizens was supposed to be regulated by their indigenous people whom they were quite familiar with such as the elders (Okfar, 2006). Nigeria has also experienced reforms which were given by the Inspector General of Police TafaBalogum and officially launched by the then president OlusegunObasanjo on April 2004. In fact, the reforms were aimed at creating a partnership between the police and the community that would ensure secure and safe environment for all people. The method has since been found to be effective in curbing crime rates as the police are no longer viewed as strangers but rather as partners in development (Ikuteyijo, 2009).

In Kenya, community policing was introduced in 2003 and officially launched by the government in April 2005 to mainly give the public ownership of the problem solving processes which was to be achieved through the police and the community working together. Its main objectives were:to promote long term conditions for development and community safety; build the capacity of the local institutions and people in the co-ordination and implementation of community policing; strengthen the co-operation and the partnership between the police and the public; strengthen interaction between and amongst the government, institutions and civil societies having an interest in promoting peace, safety and democratic policing; improve trust between the police and the community and develop linkage between development and security. Community policing was also to entail police patrols, community-police meetings, neighborhood security meetings, community cooperation with the police reservists and community policing awareness campaigns according to the Republic of Kenya (2004).

Though community policing has been very difficult to implement since its inception in 2003 and with the criminal activities such as terrorism, theft, burglary, housebreaking, armed robbery, murder and inter-ethnic clashes hitting at an all-time high, the government of Kenya has been continuously emphasizing on the need for citizens to cooperate with the government in rolling out community based policy initiatives such as the "NyumbaKumi" or "ten households" which calls for dividing neighborhoods in towns and villages nationwide into a cluster of ten houses that would help the police protect neighborhoods and guard against criminal activities.

In Nakuru Town, the level of crime has been high as it is among the fastest growing towns in Kenya. According to a research conducted by Security Research and Information Centre (SRIC, 2012) regarding crimes in urban slums in Kenya and specifically Mishomoroni in Mombasa, Kibera in Nairobi, Bondeni in Nakuru and Manyatta in Kisumu, it was found that theft (35.37\%), was the main type of crime across the four sampled slum areas. In addition, armed robbery (15.55\%), burglary/break-ins (10.67\%) and murder (23.17\%) were the other main typologies of crime in slum areas, accounting for combined $84.76 \%$ of crimes committed in slum areas in Kenya. According to National Crime Observatory Project Bi-Annual Report, (NCOPBAR) (2012), the highest number of crime incidents reported in Nakuru were 'theft' and 'Armed robbery', accounting to totals of 423 and 342 respectively. By extension, analysis from newspaper reports indicated that most of the thefts and 
robberies occurred in major urban centers, with Nairobi having the highest number followed by Nakuru (NCOPBAR, 2012). Other prevalent crimes reported in Nakuru included, murder, break-ins, domestic violence cases, rape and defilement, assault, kidnappings, and drug/firearm trafficking and possession. Figure 1 gives a summary of the average number of crime incidences of the most prevalent crimes in Nakuru Town between the period 2004 to 2014 (SRIC \& NCOPBAR, 2014).

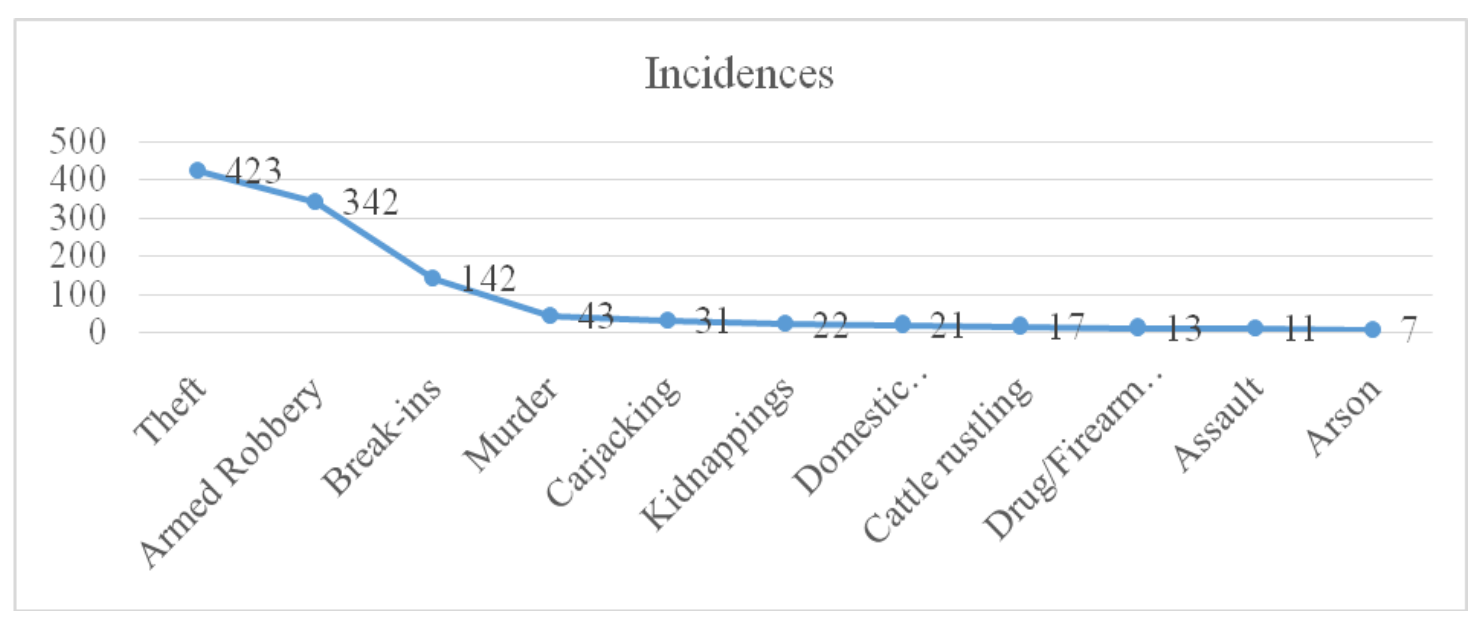

Figure1. Crime incidences in order of their prevalence in low income areas of Nakuru Town

Source: (SRIC \& NCOPBAR, 2014).

From Figure 1, it is clear that theft, Armed robbery, break-ins and murder were some of the crimes which were most prevalent in Nakuru followed by carjacking, kidnappings, domestic violence, cattle rustling, drug and firearm trafficking, assault and arson according to SRIC and NCOPBAR, 2014. Therefore, the study was only limited to the most prevalent crimes which had the highest average number of incidences reported annually. This study focused on theft and break-ins only.

\section{Purpose ANd ObJectives of The Study}

The purpose of the study was to determine the influence of community policing on incidences of theft and break-ins in low income areas of Nakuru Town. The Study was guided by the following objectives:

a) To establish the influence of community policing on incidences of theft in low income areas of Nakuru Town.

b) To determine the influence of community policing on incidences of break-ins in low income areas of Nakuru Town.

\section{HYPOTHESES}

$\mathrm{H}_{\mathrm{ol}}$ There is no statistically significant influence of community policing on the incidences of theft in low income areas of Nakuru Town.

$\mathrm{H}_{\mathrm{o} 2}$ There is no statistically significant influence of community policing on the incidences of break-ins in low income areas of Nakuru Town.

\section{Methodology}

The cross- sectional survey research design was employed in this study. The study was conducted Four (4) low income areas of Nakuru Town- Kenya. These were:Kaptembwo, Rhonda, Bondeni and Kivumbini. The target population was all the residents in the four low income areas of Nakuru Town, giving a total population of 252,762 from which a total of 156 respondents who participated was drawn.

The sample was selected purposively. First, various chiefs in Nakuru Town West and Nakuru Town East wards were identified, and then they assisted in identifying the residents who could provide the required or relevant information.The questionnaire used was researcher-administered. A structured questionnaire was used to obtain information about community policing and incidences of theft and break-ins in the four areas of study. The questionnaire was administered to 131residents who were available at the time of the research. The questionnaire contained 5 items (indicators of community 
policing) that were used to measure community policing. The residents were asked whether or not they agreed with the statements under each indicator by ticking Strongly Disagree, Disagree, Not Sure, Agree and Strongly Agree in the boxes which were provided.

\section{RESUltS}

The following two hypotheses were tested:

\section{$\mathrm{H}_{0} \mathbf{1}$ There is no statistically significant influence of community policing on the incidences of theft in low income areas of Nakuru Town}

In this section, the respondents were asked to indicate whether or not community policing has an influence on incidences of theft cases. Results are given in Table 1 below.

Table1. The test of hypothesis one $\left(H_{o} 1\right)$

\begin{tabular}{|l|c|c|c|c|}
\hline \multicolumn{1}{|c|}{$\begin{array}{c}\text { Area of } \\
\text { residence }\end{array}$} & $\begin{array}{c}\text { Community } \\
\text { Policing }\end{array}$ & $\begin{array}{c}\text { There are high incidences } \\
\text { of theft cases in my area } \\
\text { of residence }\end{array}$ & $\begin{array}{c}\text { Pearson Correlation } \\
\text { Coefficient Values }\end{array}$ & Sig. (2-tailed) \\
\hline Kaptembwo & & & $-.694^{*}$ & .000 \\
Rhonda & & & -.137 & .656 \\
Bondeni & & $-.734^{*}$ & .172 \\
Kivumbini & & & .007 \\
\hline
\end{tabular}

* - Means significant at 5\% level

Table1 above shows the results of the analysis of the hypothesis after it was tested: $H_{0} 1$ There is no statistically significant influence of community policing on the incidences of theft in low income areas of Nakuru Town. The results are as follows;

There was a statistically significant influence of community policing on the incidences of theft in Kaptembwo and Kivumbini where the Pearson correlation coefficients were -.694and -.734, respectively with the P-values of 0.000 and 0.007 , respectively. The coefficients ( $\mathrm{r}$ ) were strong negative correlations which meant that an increase in community policing practice led to theft incidences being ameliorated significantly in the two areas. Therefore, the null hypothesis $\left(\mathrm{H}_{\mathrm{o}}\right)$, 'there is no significant influence of community policing on the incidences of theft was therefore rejected and alternative hypothesis $\left(\mathrm{H}_{\mathrm{a}}\right)$ accepted.

In Rhonda and Bondeni, the Pearson's correlation coefficients (r) of the two variables i.e. community policing $(\mathrm{CP})$ and incidences of theft were not significant at $5 \%$ level.

Ho2 There is no statistically significant influence of community policing on the incidences of break-ins in low income areas of Nakuru Town

In this section, the respondents were asked to indicate whether or not community policing has an influence on incidences break-in cases. Results are given in Table 2.

Table2.The test of hypothesis one (Ho2)

\begin{tabular}{|l|c|c|c|c|}
\hline $\begin{array}{c}\text { Area of } \\
\text { residence }\end{array}$ & $\begin{array}{c}\text { Community } \\
\text { Policing }\end{array}$ & $\begin{array}{c}\text { There are high incidences of break-in } \\
\text { cases in my area of residence }\end{array}$ & $\begin{array}{c}\text { Pearson Correlation } \\
\text { Coefficient Values }\end{array}$ & $\begin{array}{c}\text { Sig. (2- } \\
\text { tailed) }\end{array}$ \\
\hline Kaptembwo & & & $-.777^{*}$ & .000 \\
Rhonda & & & -.206 & .500 \\
Bondeni & & & $-.489^{*}$ & .000 \\
Kivumbini & & & $-.833^{*}$ & .001 \\
\hline
\end{tabular}

* - Means significant at $5 \%$ level

Table 2 above shows the results of the analysis of the second hypothesis after it was tested: $\mathrm{H}_{\mathrm{o}} 2$ There is no statistically significant influence of community policing on the incidences of break-ins in low income areas of Nakuru Town. The results are as follows; There was a statistically significant influence of community policing on the incidences of break-ins in Kaptembwo, Bondeni and Kivumbini where the Pearson correlation coefficients were -.777 (strong negative correlation), -.489 (medium negative correlation)and -.833 (strong negative correlation), with the P-values less than .05. The coefficients ( $\mathrm{r}$ ) were strong, medium and strong negative correlations which mean that an increase in community policing practice leads to significant decrease in incidences of break-ins in the three areas. Therefore, the null hypothesis $\left(\mathrm{H}_{\mathrm{o}}\right)$, 'there is no significant influence of community policing on the incidences of break-ins was therefore rejected and alternative hypothesis $\left(\mathrm{H}_{\mathrm{a}}\right)$ accepted. 
In Rhonda however, the Pearson's correlation coefficient (r) of the two variables i.e. community policing $(\mathrm{CP})$ and incidences of break-ins was not significant at $5 \%$ level.

Average Correlation of Community Policing with incidences of theft and break-ins in Low Income Areas of Nakuru Town (combined)

In this section, the correlation of community policing with incidences of theft and break-ins in low income areas of Nakuru Town (combined) was conducted. Results are given in Table 3.

Table3. The Average Correlation of Community Policing with Criminal Activities in Low Income Areas ofNakuru Town (combined)

\begin{tabular}{|l|r|r|r|r|}
\hline Area of residence & $\begin{array}{r}\text { Community } \\
\text { Policing }\end{array}$ & $\begin{array}{r}\text { Criminal } \\
\text { Activities }\end{array}$ & $\begin{array}{r}\text { Pearson Correlation } \\
\text { Coefficient Value }\end{array}$ & Sig. (2-tailed) \\
\hline $\begin{array}{l}\text { Low Income Areas } \\
\text { of Nakuru Town }\end{array}$ & & & $-.655^{*}$ & .000 \\
\hline
\end{tabular}

* - Means significant at $5 \%$ level

Table 3 above gives the general analysis, Pearson's Correlation Coefficient (r) of the variables i.e. community policing (CP), theft and break-ins combined is -.655 and a significant level of .000 which is less than .05 . This means that there is a statistically significant influence of community policing on incidences of theft and break-ins in low income areas of Nakuru Town. The coefficient (r) is a strong negative correlation which means that as community policing was being practiced; incidences of theft and break-ins also reduced significantly.

\section{DISCUSSION}

According to Charlotte et al (2014), when 25 different studies containing 65 independent assessments were analyzed before and after the introduction of a range of community policing strategies in reducing criminal activities and fear of crime, the findings were that community-policing strategies have a positive effect in the reduction of individuals' perception of disorderly conduct, including drug dealing. The findings are in agreement with the present paper as community policing strategies such as CPAC, NKI, CPJM, PP and NSM were found to have reduced incidences of theft in Kaptembwo and Kivumbini and not in Rhonda and Bondeni. In Kaptembwo, community policing indicators were found to have reduced all the two crimes under study. In Bondeni, incidences of theft were reduced by $\mathrm{PP}$ while incidences of break-ins were reduced by all the indicators. In Kivumbini, incidences of theft were reduced by all the indicators except CPJM while incidences of break-ins were reduced by all the indicators. In Rhonda however, the incidences theft and break-ins were not reduced by the CP indicators.

According to Gill (2014), the researchers, based at George Mason University, Arizona State University, Hebrew University and the University of South Wales in 2014 in their book "CommunityOriented Policing to Reduce Crime, Disorder and Fear and Increase Satisfaction and Legitimacy among Citizens: A Systematic Review,sought to better understand the effects of community policing on crime, disorder, fear, and citizen satisfaction with and trust in the police. In 27 of the 65 comparisons where official crime outcomes were analyzed, community policing was associated with $5 \%$ to $10 \%$ greater odds of reduced crime. In 16 of the 65 comparisons, community policing was associated with a $24 \%$ increase in the odds of citizens perceiving improvements in disorderly conduct. While this effect was not statistically significant, the odds increased to $35 \%$ and became statistically significant when one study with a small number of observations was removed from the analysis. The findings are in agreement with the present study in that community policing has greater odds of reducing criminal activities as the results show there was a statistically significant influence of community policing on incidences of theft in Kaptembwo and Kivumbini and on incidences of breakins in Kaptembwo, Bondeni and Kivumbini. Naude (1999) posits that the relationship between the community and the police through working in cahoots did immensely resolve and prevent community crimes and social disorders in the United States of America in the early mid-1990. Naude's suggestions are also in agreement with the findings of this study. It was however only in Rhonda where the CP had no influence on the two crimes. This implies that environment has an influence on mechanisms of community policing. 


\section{CONCLUSiOnS}

a) Community policing reduces incidences of theft and break-ins as the coefficient (r) was a strong negative correlation which meant that as community policing was being practiced; incidences of theft and break-ins also reduced or become ameliorated significantly.

b) Community policing indicators such as CPAC, NKI, CPJM, PP and NSM are very essential in reducing criminal activities because areas where they were conducted had the greatest crime reduction.

c) The level of community policing was not uniform in all areas investigated.

d) There are numerous challenges facing effectiveness of community policing as noted in the areas investigated.

\section{RECOMMENDATIONS}

a) The county and the national government should sensitize the public on the need to enhance policecommunity interaction as a good measure to reduce the rate of theft and break-ins in the community.

b) The government should put in place a structure which ensures that the police and the community are able to conduct joint meetings that focuses on security issues affecting the community and how they could be addressed.

c) The members of the pubic also need to be sensitized on the importance of embracing community policing in their residential areas and on the need to take care of personal and community property.

\section{REFERENCES}

[1] Allen, M. (2005). Textbook on Criminal Law. Oxford University Press, Oxford.

[2] Charlotte, et al. (2014). Community-Oriented Policing to Reduce Crime, Disorder and Fear and Increase Satisfaction and Legitimacy among Citizens: A Systematic Review: Journal of Experimental Criminology.

[3] Diamond, K. \& Weiss, B.(2009). Community policing: Looking to Tomorrow: Police Executive Research Forum, Department of Community Oriented Policing Services.

[4] Gill et al. (2014). Community-Oriented Policing to Reduce Crime, Disorder and Fear and Increase Satisfaction and Legitimacy among Citizens: A Systematic Review: Journal of Experimental Criminology.

[5] Martin \& Jacqueline. (2006), Criminal Law for A2. Hodder Arnold. ISBN 978-0-340-91452-6.

[6] McGoey, C. (2013). Armed robbery Facts: Violent Crime against Persons. London Sage Publication.

[7] Nassiuma, D.K. (2000). Survey Sampling; Theory and Methods. Nairobi: Nairobi University Press.

[8] National Crime Observatory Project Bi-Annual Report of 2012: Security Research and Information Centre.

[9] Walker, C. (1994). An Evaluation of Community Development Block Grant Program. Urban Institute Publications: November, 1994.

\section{AUTHOR's BIOGRAPHY}

Professor Mark I. O. Okere, is the Academic Coordinator of Master of Research and Public Policy (MRPP) in the Department of Curriculum, Instruction \& ducational Management at Egerton University. Professor Okere has extensive experience in research in Education, Social sciences and Security Studies. Dr. Eric K. Bor is senior Lecturer in the Department of Peace, Security and Social Studies at Egerton University, Kenya. Has extensive experience in security studies. Mr. Kennedy O. Ogutu holds a Master of Research \& Public Policy (MRPP) degree from Egerton University. Has served as Volunteer Tutor and Trainer at Kenya Institute of Security and Criminal Justice, and volunteer Civilian Criminal Investigation Officer in Nakuru Kenya

Citation: Kennedy, O. Ogutu et al. "Influence of Community Policing on Incidences of Criminal Activities in Low Income Areas of Nakuru Town, Kenya." International Journal of Humanities Social Sciences and Education (IJHSSE), vol 4, no. 9, 2017, pp. 52-57. doi:http://dx.doi.org/10.20431/2349-0381.0409008.

Copyright: () 2017 Authors. This is an open-access article distributed under the terms of the Creative Commons Attribution License, which permits unrestricted use, distribution, and reproduction in any medium, provided the original author and source are credited. 